\title{
Algae viability within copepod faecal pellets: evidence from microscopic examinations
}

\author{
Sandra Jansen*, Ulrich Bathmann \\ Alfred Wegener Institute for Polar and Marine Research, Am Handelshafen 12, 27570 Bremerhaven, Germany
}

\begin{abstract}
The viability of different phytoplankton species within copepod faecal pellets was tested. Monocultures of the dinoflagellate Scrippsiella trochoidea and the diatoms Fragilariopsis kerguelensis, Proboscia alata and Chaetoceros dichaeta were fed to Calanus helgolandicus, Temora longicornis and Centropages typicus. Microscopic observations of faecal pellet content, chlorophyll auto-fluorescence and the fluorescence of cells stained with the viability stain fluorescein diacetate (FDA) revealed that some $S$. trochoidea cells survived the gut passage of $T$. longicornis and $C$. typicus. Viable cells of $F$. kerguelensis were observed in faecal pellets of all copepod species investigated. The 2 diatom species $P$. alata and $C$. dichaeta were reduced to small fragments within all faecal pellets, and hence did not survive grazing by any of the 3 copepod species.
\end{abstract}

KEY WORDS: Algae viability $\cdot$ Faecal pellets $\cdot$ Copepods $\cdot$ Fluorescein diacetate $\cdot$ FDA Resale or republication not permitted without written consent of the publisher

\section{INTRODUCTION}

Copepod faecal pellets are of interest not only in zooplankton ecology, but also in studies of biogeochemical cycles and export fluxes in the ocean (Turner 2002). Copepods reduce the vertical flux of phytoplankton through grazing, but may also enhance the vertical flux of phytoplankton-derived material through production of fast-sinking faecal pellets. In general, faecal pellets produced by zooplankton species have sinking velocities of up to several hundred meters per day (Turner 2002 and references therein). Their contribution to total material flux is highly variable, between $<1$ and $\leq 99 \%$ (Bathmann et al. 1987, Viitasalo et al. 1999, Wexels Riser et al. 2001, Turner 2002), but the majority of studies report relatively low faecal pellet export rates as a fraction of total particulate organic carbon (POC) content in the water. Low faecal pellet export rates suggest that faecal material is recycled within the euphotic zone rather than being exported (e.g. Lampitt et al. 1990, Viitasalo et al. 1999, Wexels Riser et al. 2001).

The fate of material stemming from faecal pellets recycled in the upper ocean depends on the condition of the material enclosed within the faecal pellets Thus, it is crucial to know how grazing affects ingested phytoplankton cells. Can phytoplankton cells survive grazing, or does grazing result in certain death? Not all food items undergo the same degree of fragmentation during feeding by copepods (Honjo \& Roman 1978, Turner \& Ferrante 1979), and several studies reported signs of intact (e.g. Bathmann \& Liebezeit 1986, Wexels Riser et al. 2003), and in some cases even viable (Fowler \& Fisher 1983), cells inside faecal pellets. Most of these studies used scanning electron microscopy (SEM) to examine faecal pellet contents. These images give good qualitative information on the degree of fragmentation, but observations of intact cells within faecal pellets give no information on viability. Especially with regard to algae species surrounded by mineral skeletons, such as diatoms with their silica frustules, microscopic differentiation between metabolically active (alive, viable) and intact but dead cells is not possible. Growth experiments with freshly produced faecal pellets will underestimate cell viability, because some phytoplankton species like Dinophysis spp. do not grow under culture conditions. 
In view of the need for a fast and precise evaluation of the physiological state of algae within faecal pellets, we applied a direct microscopical fluorescence method. The fluorescence dye fluorescein diacetate (FDA) was first used $40 \mathrm{yr}$ ago as a stain to indicate viability of mammalian cells (Rotman \& Papermaster 1966), and has also been shown to be an effective viability stain for plant cells, fungi, protozoa and bacteria, as well as for phytoplankton (Pouneva 1997, Jochem 1999, Agusti \& Sanchez 2002). The non-polar and non-fluorescent FDA molecules enter freely into the cell, where they are hydrolysed by non-specific esterases. The resulting fluorescein is polar and fluorescent and therefore retained within the cell by the intact membrane of live cells. In this way, FDA stains all cells characterised by esterase activity and intact cell membranes, i.e. viable cells (Rotman \& Papermaster 1966, Pouneva 1997, Jochem 1999, Agusti \& Sanchez 2002). Therefore, viable cells are clearly distinguishable from dead cells, in which either the fluorescing part of the FDA is not hydrolysed owing to enzyme inactivity, or the split fluorescing component passes through the destroyed cell wall and does not accumulate.

The aim of the present work was to study the fate of different algae species within faecal pellets of common North Sea copepods. The direct method of FDA staining was used to determine if cells can survive grazing and digestion, possibly as a result of protection against physical or chemical destruction.

\section{MATERIALS AND METHODS}

Algae collection and cultivation. The chain-forming diatoms Fragilariopsis kerguelensis, Proboscia alata and Chaetoceros dichaeta were isolated during 'Polarstern' cruise ANT XXI/3 to the Atlantic sector of the Southern Ocean (approximately $49^{\circ} \mathrm{S}, 02^{\circ} \mathrm{E}$ ). The diatoms were isolated from samples collected with a plankton net and cultivated at $4^{\circ} \mathrm{C}$. F. kerguelensis was selected because of its heavily silicified frustules. Cells of $P$. alata are elongated and cylindrical in shape, with weakly silicified frustules. C. dichaeta is characterised by long hollow spines that protrude from the 4 corners of rectangular cells, and as opposed to the other 2 species its frustules exhibit an intermediate degree of silification.

The dinoflagellate Scrippsiella trochoidea was isolated in August 2001 during 'Heincke' cruise HE152 to the North Sea. It was grown in a temperaturecontrolled room at $15^{\circ} \mathrm{C}$. S. trochoidea live as single, motile cells. Instead of the silicified frustule of the diatoms, this dinoflagellate is covered by a theca, which is a complicated construction consisting of an outer membrane with underlying membrane vesicles containing thecal plates. All phytoplankton cultures were grown in sterile filtered seawater, enriched with nutrients according to f/2 medium (Guillard \& Ryther 1962).

Copepod collection and experimental setup. Copepods were collected with a $160 \mu \mathrm{m}$-mesh zooplankton net at the permanent station Helgoland Roads in the North Sea $\left(54^{\circ} 11^{\prime} \mathrm{N}, 7^{\circ} 54^{\prime} \mathrm{E}\right)$ in November 2005. After retrieval, copepods were kept in 101 filtered seawater and stored cold and dark until further handling in the laboratory. After some hours, females of the abundant copepod species Calanus helgolandicus, Temora longicornis and Centropages typicus were sorted out under a binocular microscope. Copepods were acclimated for 8 to $12 \mathrm{~h}$ in $1 \mathrm{l}$ beakers containing one of the 4 algae species in monoculture. After acclimatisation, copepods were transferred to $1 \mathrm{l}$ bottles containing the same algae species, and mounted on a slowly rotating plankton wheel. Experiments were conducted in a $15^{\circ} \mathrm{C}$ temperature-controlled room using algae concentrations of $\sim 800 \mu \mathrm{g} \mathrm{C}^{-1}$. This corresponded to 4800, 100, 3700 and 2000 cells $\mathrm{ml}^{-1}$ for Fragilariopsis kerguelensis, Proboscia alata, Chaetoceros dichaeta and Scrippsiella trochoidea, respectively (Menden-Deuer \& Lessard 2000, Montresor et al. 2003). After 12 to 16 $\mathrm{h}$, the content of each bottle was gently sieved through a $30 \mu \mathrm{m}$ mesh to collect the produced faecal pellets. Faecal pellet samples were prepared for SEM (Wexels Riser et al. 2003) and micrographs were taken using a Quanta 200F/FEI. Replicate faecal pellet samples were directly used for the FDA staining procedure.

FDA staining. The viability of cells within faecal pellets was monitored using FDA. The FDA stock solution of $5 \mathrm{mg} \mathrm{ml}^{-1}$ was prepared with dimethylsulfoxide (DMSO) and stored at $4^{\circ} \mathrm{C}$ according to Jochem (1999). The working solution was prepared directly before usage by diluting the stock solution 100-fold with chilled, distilled water (Jochem 1999). Faecal pellets were carefully cleaned with filtered seawater, transferred to a $3 \mathrm{ml}$ Utermöhl chamber and stained with $100 \mu$ l of the FDA working solution. No fixatives were used prior to microscopic observations. After 10 min dark storage on ice, the sample could be viewed under an inverted fluorescence microscope (Zeiss, Axiovert 200). Viable cells showed green fluorescence (wavelength 520 to $530 \mathrm{~nm}$ ) after excitation with blue light of wavelength $495 \mathrm{~nm}$. In our samples, the red chl a auto-fluorescence masked the green FDA fluorescence, which was also observed for other phytoplankton species (e.g. Pouneva 1997). Red fluorescence is not an indicator of viabil- 

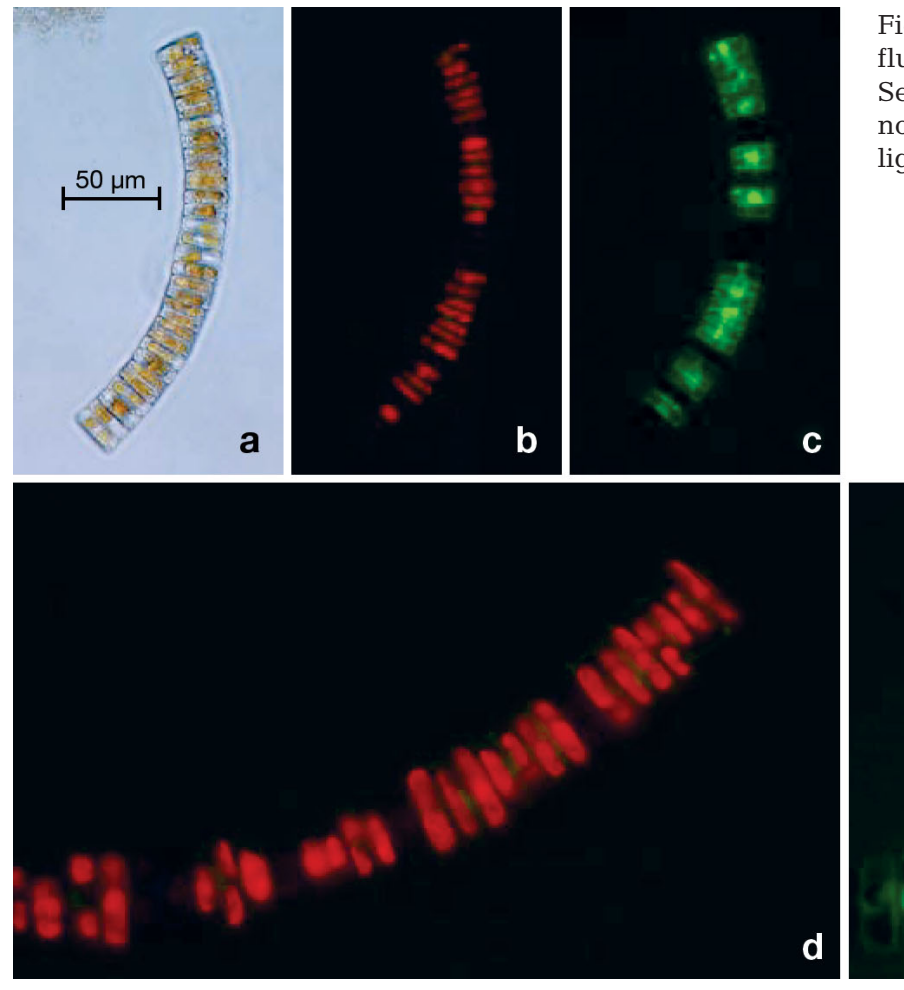

ity, and dead cells may autofluoresce for months after cell death. However, the use of Filter Set 44 by Zeiss (excitation filter: BP 475/40; beam splitter: FT 500; emission: BP 530/50) remedies this problem by masking the red auto-fluorescence and making the green viability fluorescence visible. Fig. 1b,d shows a Fragilariopsis kerguelensis chain after FDA staining under fluorescent light (450 to $500 \mathrm{~nm}$ ); the green FDA fluorescence is masked by the red chl a autofluorescence. After additional use of Filter Set 44, only the green FDA fluorescence remains visible (Fig. 1c,e). However, the green fluorescence was weak in most cases and faded rapidly; hence, it was not always possible to obtain photographs of FDAstained cells in faecal pellets that exhibited green fluorescence.

\section{RESULTS}

Faecal pellets were produced by all 3 copepod species investigated. The size of faecal pellets varied according to copepod body size: Calanus helgolandicus produced the largest faecal pellets, followed by Temora longicornis and Centropages typicus.

Fig. 2 shows faecal pellets produced by Calanus helgolandicus, Temora longicornis and Centropages typicus after grazing on the dinoflagellate Scrippsiella trochoidea. Within faecal pellets produced by
Fig. 1. Fragilariopsis kerguelensis. Cell chain stained with fluorescein diacetate (FDA) with and without Zeiss' Filter Set 44. (a) Visible light, no filter; (b) fluorescence light, no filter; (c) fluorescence light, with filter; (d) fluorescence light, no filter; (e) fluorescence light, with filter. (a-c) $200 \times$, (d,e) $400 \times$ magnification

C. helgolandicus, S. trochoidea cells appeared crushed and no green fluorescence was observed. These faecal pellets had a homogeneous content (Fig. 2a). However, within the faecal pellets of T. longicornis and C. typicus, intact cells of $S$. trochoidea could be identified (Fig. 2b,d). These cells looked intact and undigested, with strong red chl a auto-fluorescence (Fig. 2c,e). Green fluorescence from the FDA stain was also clearly visible within faecal pellets of $T$. longicornis and C. typicus after grazing on S. trochoidea, indicating that individual cells of this species can survive gut passage.

Intact cells of Fragilariopsis kerguelensis could be identified within faecal pellets produced by all 3 copepod species (Fig. 3). SEM pictures show faecal pellets of Calanus helgolandicus and Temora longicornis in detail (Fig. 4): several broken frustules are visible within the faecal pellets, and complete and undigested cells can also be seen, especially within chains. Green fluorescence from FDA staining could be seen in faecal pellets produced by all the copepod species grazing on F. kerguelensis (Fig. 5).

Grazing on monocultures of the remaining 2 diatoms (Proboscia alata and Chaetoceros dichaeta) resulted in faecal pellets in which no intact cells could be observed. Cells were reduced to small fragments during grazing, and faecal pellets were exclusively packed with cell debris. Photos taken under the light microscope showed faecal pellets of all 


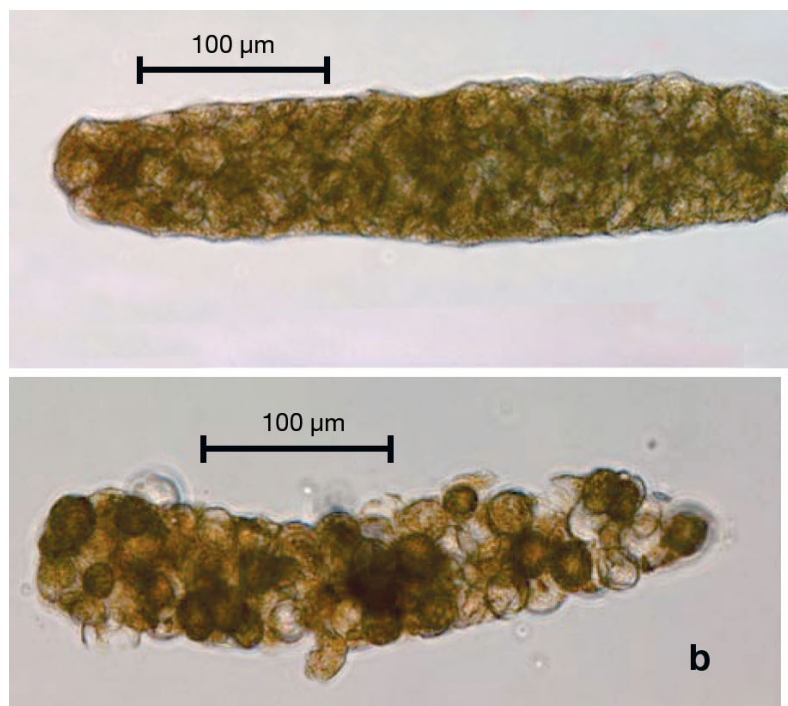

Fig. 2. Faecal pellets of copepod species fed a monoculture of Scrippsiella trochoidea. (a) Calanus helgolandicus (visible light); (b) Temora longicornis (visible light); (c) $T$. longicornis (fluorescence light); (d) Centropages typicus (visible light); and (e) C. typicus (fluorescence light). (c,e) Chl a autofluorescence masks the FDA fluorescence

a of cells within the faecal pellets
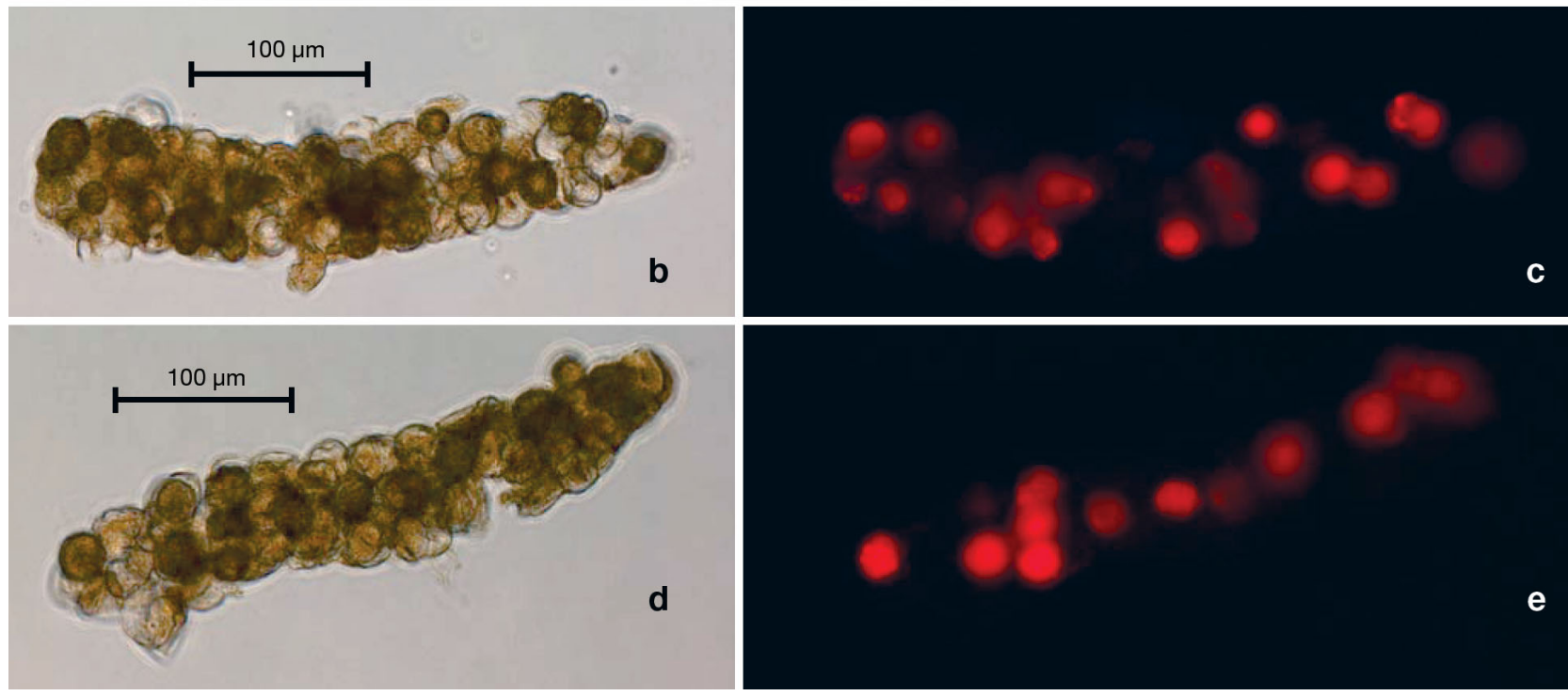

copepod species to comprise an indefinable, homogeneous, brownish content (Figs. 6 \& 7). Faecal pellets produced by Calanus helgolandicus are shown in more detail in SEM images in Fig. 8. Faecal pellets produced by all species after consuming $P$. alata were exclusively filled with flake-like cell debris (e.g.

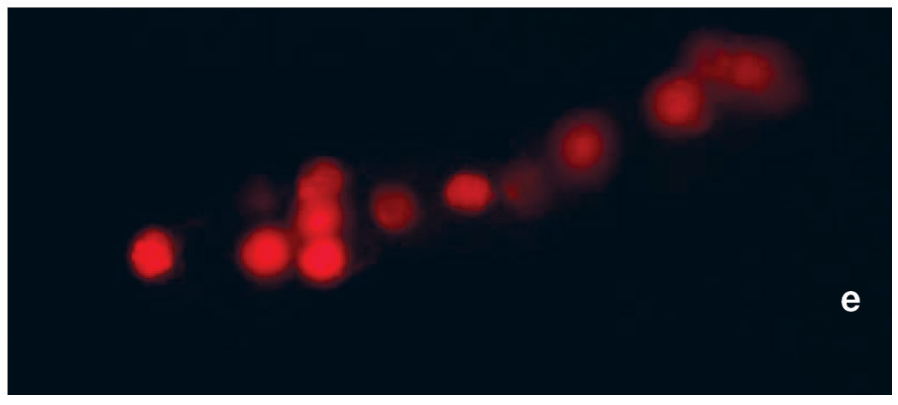

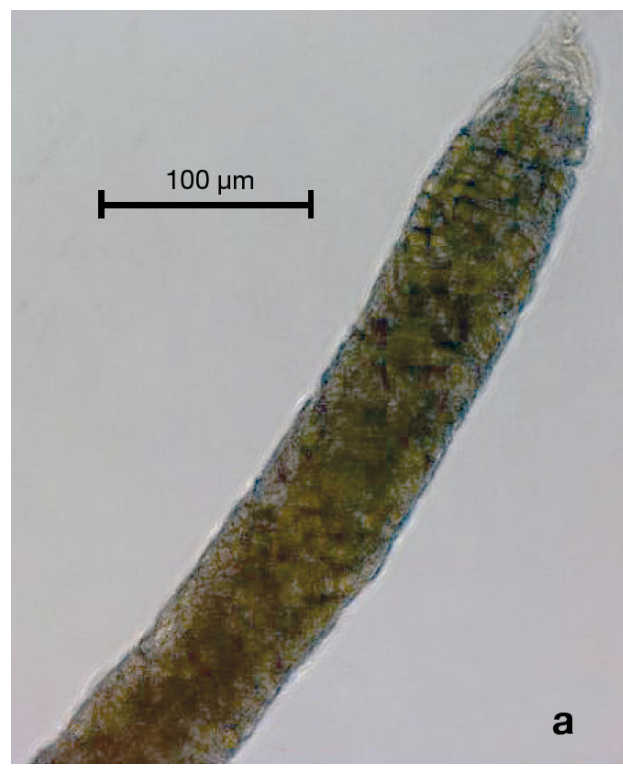
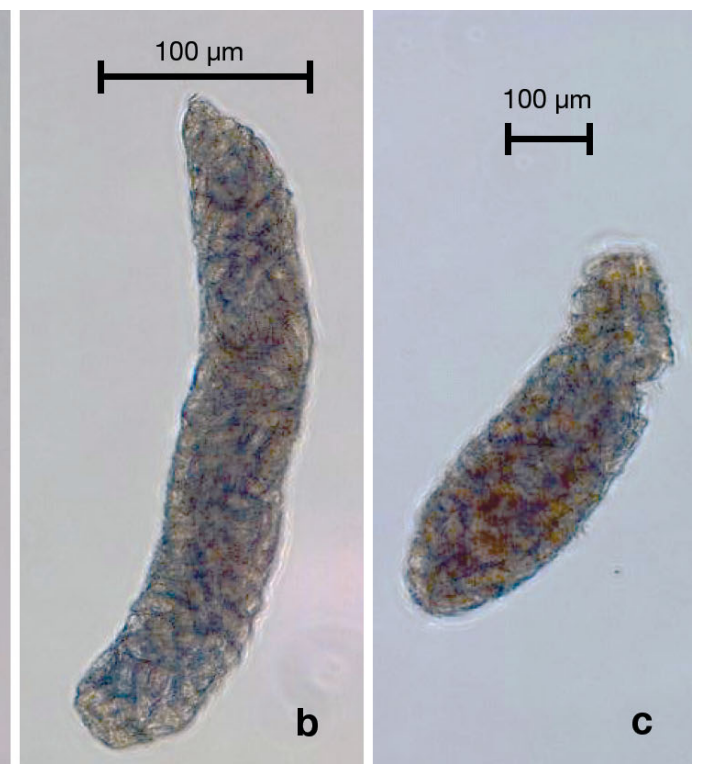

Fig. 3. Faecal pellets of (a) Calanus helgolandicus, (b) Temora longicornis and (c) Centropages typicus fed a monoculture of Fragilariopsis kerguelensis

Fig. 8a). Within faecal pellets that contained $C$. dichaeta, many identifiable fragments of spines were visible in addition to cell debris (Fig. 8b). Neither intact cells nor fluorescein fluorescence were observed in any faecal pellets produced after consumption of $P$. alata or C. dichaeta. 

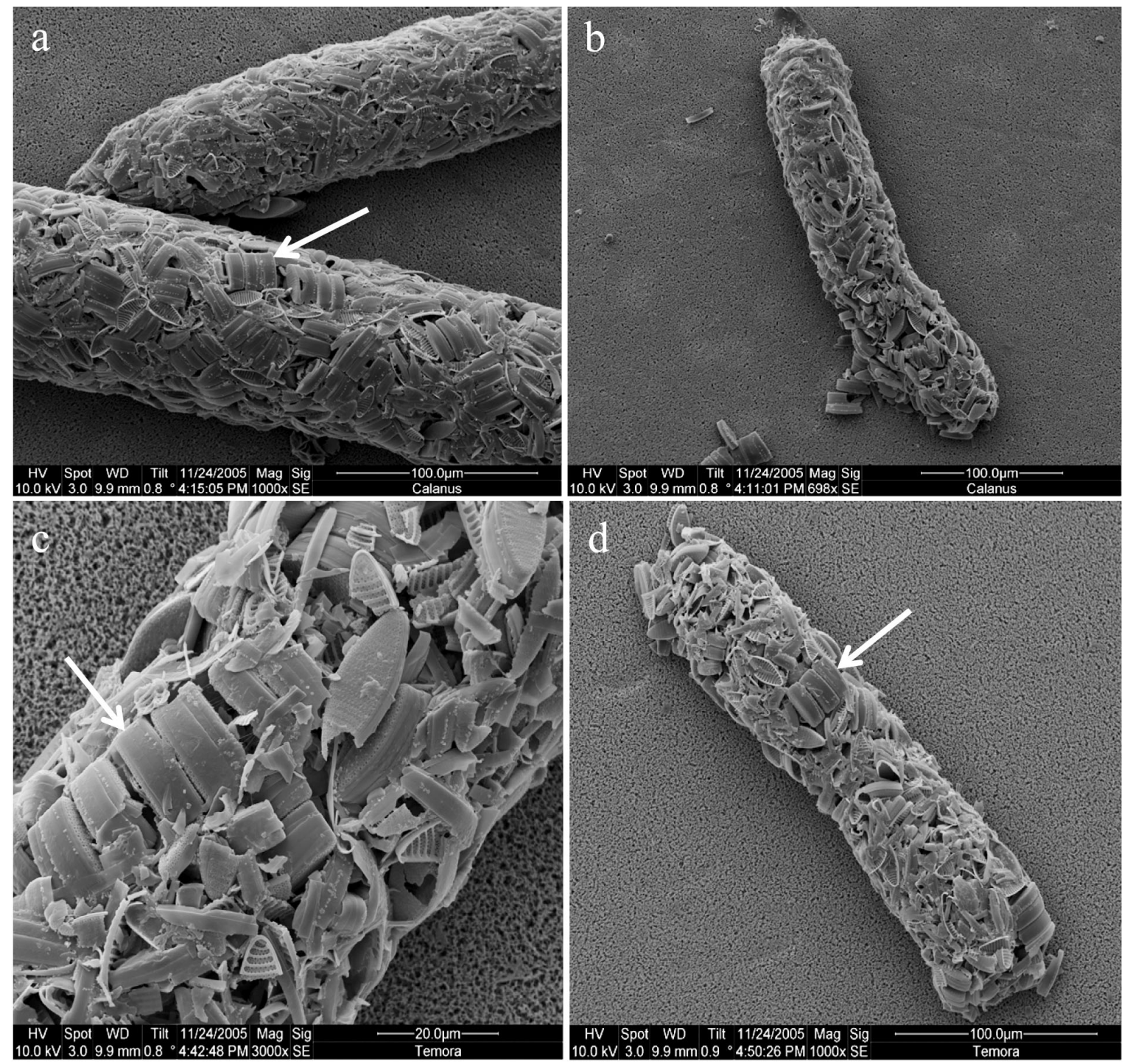

Fig. 4. SEM images of faecal pellets produced by (a,b) Calanus helgolandicus and (c,d) Temora longicornis fed a monoculture of Fragilariopsis kerguelensis. Arrows mark apparently intact cells within chains
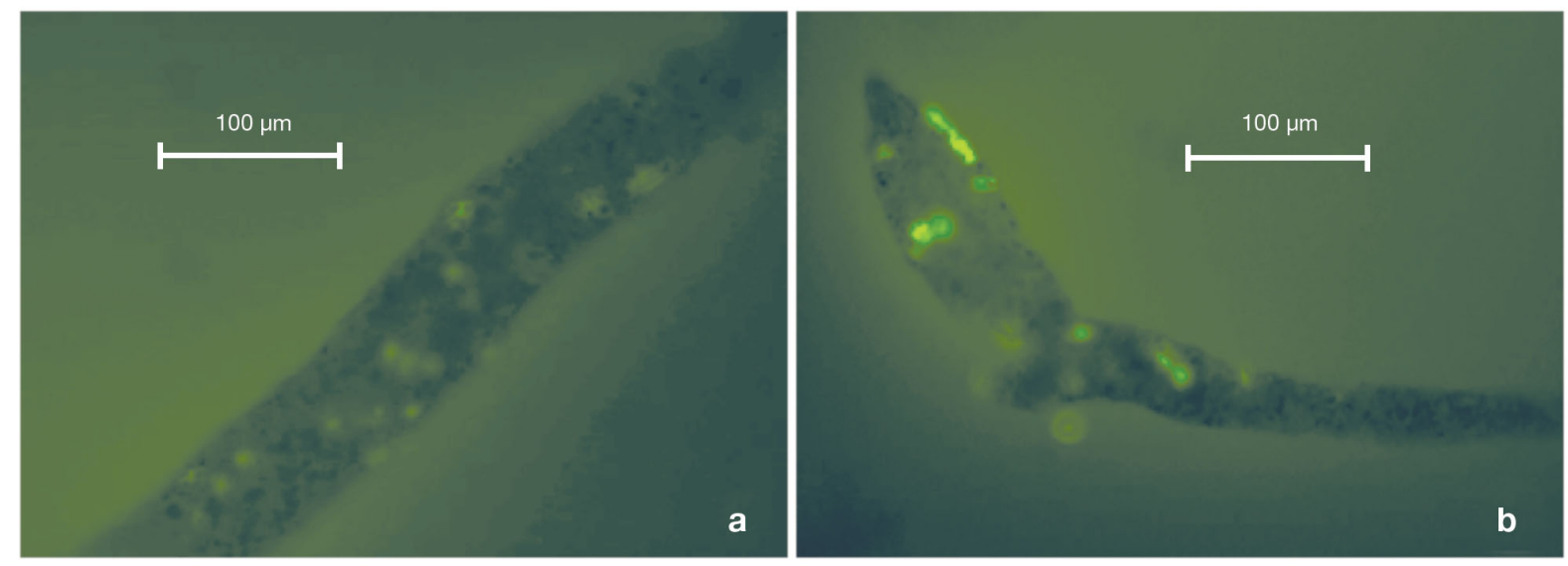

Fig. 5. Faecal pellets of (a) Calanus helgolandicus and (b) Temora longicornis fed a monoculture of Fragilariopsis kerguelensis. Green fluorescence after FDA staining indicates viable cells within pellets 

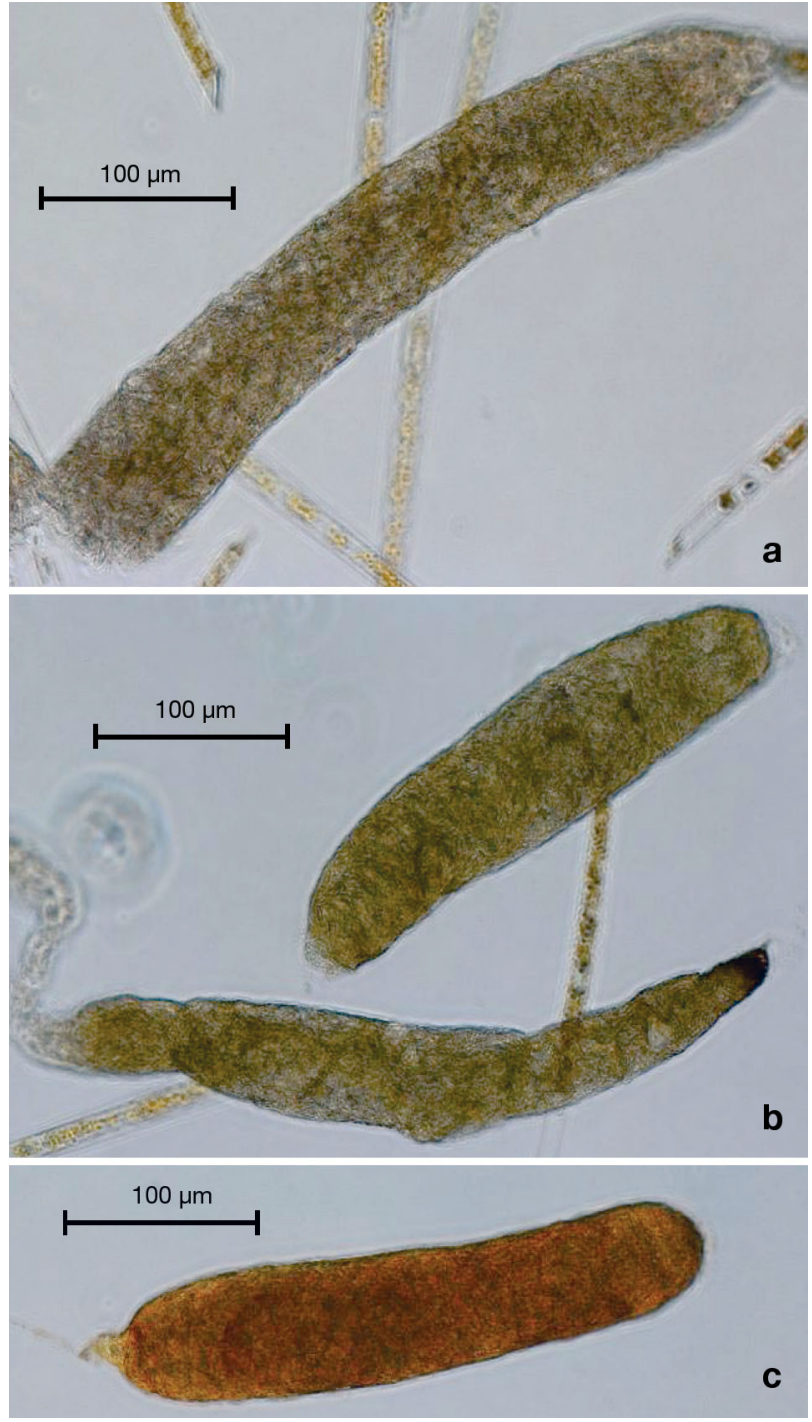

Fig. 6. Faecal pellets of (a) Calanus helgolandicus, (b) Temora longicornis and (c) Centropages typicus fed a monoculture of Proboscia alata. Intact cells are visible in the background of (a) and (b). The content of all faecal pellets looks homogeneous

\section{DISCUSSION}

In the present study we demonstrated that cells of some phytoplankton species might survive copepod gut passage. The condition of the phytoplankton cells enclosed in faecal pellets is presumably unimportant if pellets sink to the deep ocean; however, detrital faecal pellet content can serve as a source of nutrients for viable phytoplankton cells within the pellets, which in turn can act as a seeding population if they are recycled or brought back to the euphotic zone and conditions are suitable. There is increasing evidence that a large proportion of zooplankton faecal pellets is re-
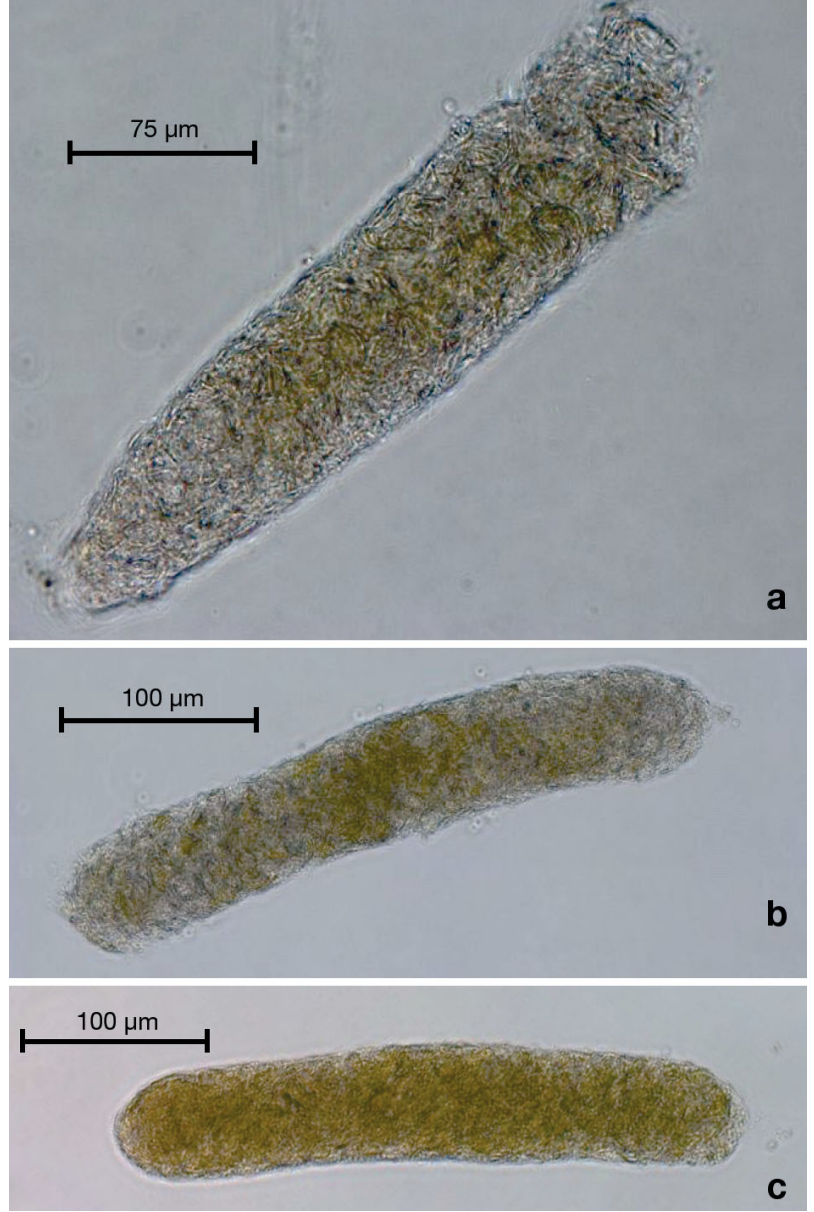

Fig. 7. Faecal pellets of (a) Calanus helgolandicus, (b) Temora longicornis and (c) Centropages typicus fed a monoculture of Chaetoceros dichaeta

cycled in the water column through microbial decomposition and zooplankton activity (e.g. Lampitt et al. 1990, Noji et al. 1991, Hansen et al. 1996, Turner 2002). The longer the residence time that faecal pellets have in the euphotic zone, the more likely it is that pellets will be recycled. The residence time of faecal pellets is dependent on various factors, including sinking speed, which is primarily dependent on the size and density of the faecal pellet as well as on diet composition and concentration (Butler \& Dam 1994, Hansen et al. 1996, Feinberg \& Dam 1998). The degradation rate of faecal pellets also depends on a number of factors, including diet (Hansen et al. 1996). Experiments conducted by Hansen et al. (1996) revealed rapid microbial degradation of Acartia tonsa faecal pellets when feeding on Rhodomonas baltica in excess concentrations: more then $90 \%$ of faecal pellets were degraded within the first $24 \mathrm{~h}$. 

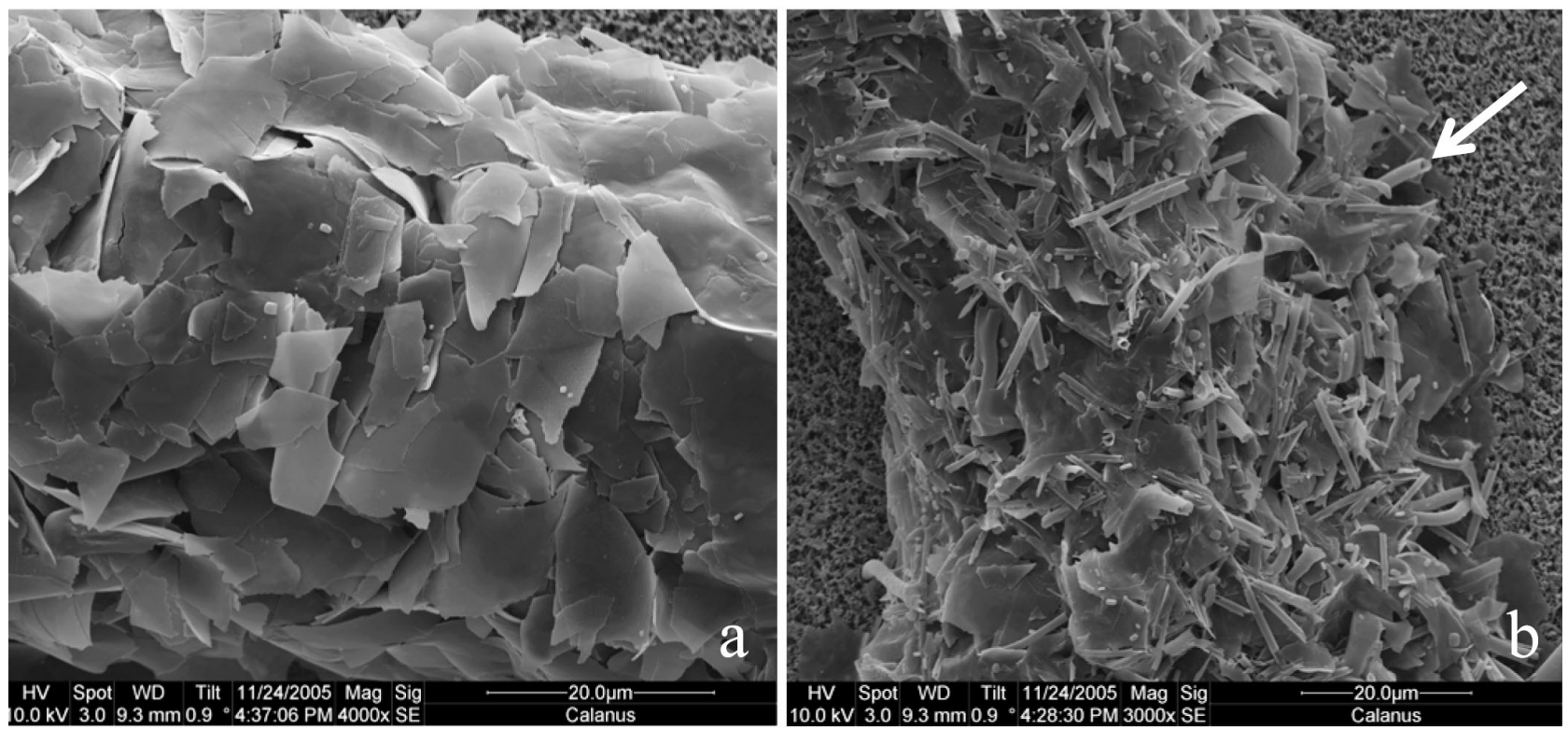

Fig. 8. SEM images of faecal pellets produced by Calanus helgolandicus grazing on (a) Proboscia alata and (b) Chaetoceros dichaeta. Pellets of $C$. helgolandicus are shown as an example; those of other copepod species looked similar. Faecal pellets containing $P$. alata show flake-like cell debris of the diatom $(a) ; C$. dichaeta cells within faecal pellets are likewise reduced to small pieces (b), but fragments of spines are also visible (arrow)

Zooplankton activity like coprorphagy (ingestion of faecal pellets), coprorhexy (fragmentation of faecal pellets) and coprorchaly (loosening of faecal pellets) may contribute significantly to increased resistance time of faecal pellets within the euphotic zone, owing to reduced sinking velocity (Lampitt et al. 1990, Noji et al. 1991). The cyclopoid copepod Oithona spp. is one of the species assumed to feed efficiently on faecal pellets (Gonzalez \& Smetacek 1994). However, recent studies did not support these findings and found no or only minor signs of faecal pellet ingestion by copepod species such as Oithona spp., Acartia tonsa and Temora longicornis (Poulsen \& Kiørboe 2005, Reigstad et al. 2005). A. tonsa, T. longicornis, Acartia clausi and Calanus finmarchicus have been observed to fragment rather then ingest faecal pellet material (Noji et al. 1991, Poulsen \& Kiørboe 2005). Recycling of faecal pellets is a process that keeps organic material in the water column, and is therefore important for many ongoing processes in the water column.

As demonstrated in the present study, cells of some algae species can remain viable within copepod faecal pellets, implying that these cells survive the processes of grazing and digestion. If released from faecal pellets, such cells can potentially grow under favourable conditions as a result of the possible recycling mechanisms discussed above. The ability to survive grazing may be interpreted as an evolutionary defence strategy against zooplankton grazing. The interaction between phytoplankton and zooplankton has been suggested to be one of the most important factors driving planktonic evolution in the ocean (Smetacek 2001): zooplankton evolves more effective feeding strategies, while phytoplankton in turn evolves more effective defence strategies against grazing. Diatom frustules are suggested to be such a defence strategy, because they may provide effective mechanical protection against crushing thanks to their architecture and material properties of the diatom silica (Hamm et al. 2003). Copepods in turn have developed mandibles that contain silica and are strong enough to crack these frustules and take advantage of the nutritious content of the diatoms.

The frustules of Fragilariopsis kerguelensis are particularly thick. Some of the cells escaped digestion in the present experiments and stayed intact and alive after gut passage. SEM pictures revealed that many intact cells formed parts of a chain, suggesting that this alga may additionally benefit from chain formation, increasing its chance of survival when it is grazed. In contrast, the chain-forming, spiny diatom Proboscia alata did not escape digestion, and the long spines of Chaetoceros dichaeta provided no efficient protection against copepod grazing. Both of these diatoms have thin frustules relative to those of $F$. kerguelensis. It appears that the combination of chain formation and strong frustules may provide protection against destruction of cells, and allow individual cells of F. kerguelensis to remain viable after gut passage. 
Copepods were grazing on monocultures in the present study, but they may possibly avoid predating such algae in the field because of their structural defences. However, faecal pellets collected in the field frequently contain intact F. kerguelensis cells (authors' pers. obs.), and the North Sea copepods were evidently able to graze on the Antarctic diatoms under investigation.

Among dinoflagellates, it is mostly the resting stages that are assumed to serve as protection against grazing (Montresor et al. 2003); however, there are observations to suggest that vegetative cells of Dinophysis norvegica may also escape digestion (Wexels Riser et al. 2003). In the present study, viable cells were found in faecal pellets produced by Temora longicornis and Centropages typicus when grazing on vegetative cells of Scrippsiella trochoidea. Faecal pellets produced by Calanus helgolandicus contained no viable S. trochoidea cells. Montresor et al. (2003) described faecal pellets of Acartia clausi, C. typicus and Temora stylifera to contain a homogeneous and compact content, greenish-brown in colour. Only a low number of apparently intact cells was recognized within faecal pellets of T. stylifera (Montresor et al. 2003). In the present study, digestion resistance may have resulted from the rapid gut transit of animals grazing at high cell densities ( 2000 cells $\mathrm{ml}^{-1}$, corresponding to $\left.800 \mu \mathrm{g} \mathrm{C} \mathrm{l}^{-1}\right)$, in

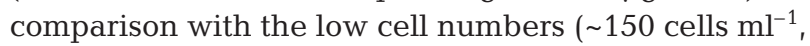
corresponding to $50 \mu \mathrm{g} \mathrm{C}^{-1}$ ) used by Montresor et al. (2003). Whether the survival of individual $S$. trochoidea cells in some but not other copepods is related to different gut passage times or to differences in handling among copepod species is uncertain, and requires further investigation whereby faecal pellets produced by different species feeding at different algal concentrations are analysed. The viability of algae within faecal pellets reveals possible pathways for phytoplankton cells to the deep sea; alternatively, such algae may serve to reseed the phytoplankton community in the overlying surface waters with vegetative cells or resting spores. It is known that phytoplankton cells are generally able to survive prolonged periods in darkness (e.g. Peters \& Thomas 1996, Jochem 1999); intact cells within faecal pellets may therefore survive for several weeks - even in deeper water layers before sufficient upward transport mechanism such as mixing and upwelling bring them back to the euphotic zone.

We conclude that FDA staining is a valid, simple and rapid method to determine the viability of single algae cells within copepod faecal pellets in vitro as well as in situ. This method provides a good tool to help elucidate ecological processes related to phytoplankton seeding strategies, the role of faecal pellets in marine ecosystems and trophic energy transfer.
Acknowledgements. We thank U. Passow for assistance with FDA staining. C. Augustin, P. Assmy and U. Tillmann kindly provided copepods and algae cultures. Comments by C. Wexels Riser, U. Passow, T. Noji and 2 anonymous reviewers are gratefully acknowledged.

\section{LITERATURE CITED}

Agusti S, Sanchez C (2002) Cell viability in natural phytoplankton communities quantified by a membrane permeability probe. Limnol Oceanogr 47:818-828

Bathmann U, Liebezeit G (1986) Chlorophyll in copepod fecal pellets: changes in the pellet numbers and pigment content during a decline Baltic spring bloom. PSZN I: Mar Ecol 7:59-73

Bathmann UV, Noji TT, Voss M, Peinert R (1987) Copepod fecal pellets: abundance, sedimentation and content at a permanent station in the Norwegian Sea in May/June 1986. Mar Ecol Prog Ser 38:45-51

Butler M, Dam HG (1994) Production rates and characteristics of fecal pellets from the copepod Acartia tonsa under simulated phytoplankton bloom conditions: implications for vertical fluxes. Mar Ecol Prog Ser 114: 81-91

Feinberg LR, Dam HG (1998) Effects of diet on dimensions, density and sinking rates of fecal pellets of the copepod Acartia tonsa. Mar Ecol Prog Ser 175:87-96

Fowler SW, Fisher NS (1983) Viability of marine phytoplankton in zooplankton fecal pellets. Deep-Sea Res 30: 963-969

González HE, Smetacek VS (1994) The possible role of the cyclopoid copepod Oithona in retarding vertical flux of zooplankton faecal material. Mar Ecol Prog Ser 113: 233-246

Guillard RRL, Ryther JH (1962) Studies on marine planktonic diatoms Cyclotella nana (Hustedt) and Detonula confervaceae (Cleve) Gran. Can J Microbiol 8:229-239

Hamm CE, Merkel R, Springer O, Jurkojc P, Maier C, Prechtel K, Smetacek V (2003) Architecture and material properties of diatom shells provide effective mechanical protection. Nature 421:841-843

Hansen B, Fotel FL, Jensen NJ, Madsen SD (1996) Bacteria associated with a marine planktonic copepod in culture. II. Degradation of fecal pellets produced on a diatom, a nanoflagellate or a dinoflagellate diet. J Plankton Res 18: $275-288$

Honjo S, Roman MR (1978) Marine copepod fecal pellets: production, preservation and sedimentation. J Mar Res 36: 45-57

Jochem FJ (1999) Dark survival strategies in marine phytoplankton assessed by cytometric measurement of metabolic activity with fluorescein diacetate. Mar Biol 135: 721-728

Lampitt RS, Noji T, Bodungen Bv (1990) What happens to zooplankton faecal pellets? Implications for material flux. Mar Biol 104:15-23

Menden-Deuer S, Lessard EJ (2000) Carbon to volume relationships for dinoflagellates, diatoms and other protist plankton. Limnol Oceanogr 45:569-579

Montresor M, Nuzzo L, Mazzocchi MG (2003) Viability of dinoflagellate cysts after the passage through the copepod gut. J Exp Mar Biol Ecol 287:209-221

Noji TT, Estep KW, Macintyre F, Norrbin F (1991) Image analysis of faecal material grazed upon by three species of copepods: evidence for coprorhexy, coprophagy and coprochaly. J Mar Biol Assoc UK 71:465-480 
Peters E, Thomas DN (1996) Prolonged darkness and diatom mortality I: marine Antarctic species. J Exp Mar Biol Ecol 207:25-41

Poulsen LK, Kiørboe T (2005) Coprophagy and coprorhexy in the copepods Acartia tonsa and Temora longicornis: clearance rates and feeding behaviour. Mar Ecol Prog Ser 299: $217-227$

Pouneva I (1997) Evaluation of algal culture viability and physiological state by fluorescent microscopic methods. Bulg J Plant Physiol 23:67-76

Reigstad M, Wexels Riser C, Svensen C (2005) Fate of copepod faecal pellets and the role of Oithona spp. Mar Ecol Prog Ser 304:265-270

Rotman B, Papermaster BW (1966) Membrane properties of living mammalian cells as studied by hydrolysis of fluorogenic esters. Proc Natl Acad Sci USA 55:134-141

Smetacek VS (2001) A watery arms race. Nature 411:745

Editorial responsibility: Otto Kinne (Editor-in-Chief), Oldendorf/Luhe, Germany
Turner JT (2002) Zooplankton fecal pellets, marine snow and sinking phytoplankton blooms. Aquat Microb Ecol 27: $57-102$

Turner JT, Ferrante JG (1979) Zooplankton fecal pellets in aquatic ecosystems. Bioscience 29:670-677

Viitasalo M, Rosenberg M, Heiskanen AS, Koski M (1999) Sedimentation of copepod fecal material in the coastal northern Baltic Sea: Where did all the pellets go? Limnol Oceanogr 44:1388-1399

Wexels Riser C, Wassmann P, Olli K, Arashkevich E (2001) Production, retention and export of zooplankton faecal pellets on and off the Iberian shelf, north-west Spain. Prog Oceanogr 51:423-441

Wexels Riser C, Jansen S, Bathmann U, Wassmann P (2003) Grazing of Calanus helgolandicus on Dinophysis norvegica during bloom conditions in the North Sea: evidence from investigations of faecal pellets. Mar Ecol Prog Ser 256:301-304

Submitted: February 28, 2006; Accepted: August 31, 2006 Proofs received from author(s): April 25, 2007 